\title{
Saving Peace Education: The Case of Israel
}

\author{
Nurit Basman-Mor ${ }^{1}$ \\ ${ }^{1}$ School of Education, Kaye Academic College, Beer-Sheva, Israel \\ Correspondence: Nurit Basman-Mor, 6 Azriel Nitzani St. P.O.B 4301, Beer-Sheva 8414201, Israel. Tel: \\ 972-546-668-140. E-mail: nuritbasman@gmail.com
}

Received: October 27, 2020

Accepted: November 20, 2020

Online Published: November 30, 2020

doi:10.5539/hes.v11n1p18

URL: https://doi.org/10.5539/hes.v11n1p18

\begin{abstract}
In the divided society of Israel, educators committed to the future and the well-being of young people should incorporate peace education in all the dimensions of doing and learning in the educational system. While the formal educational system does not have a peace education policy, throughout the country, many schools undertake diverse practices of peace education. However, these practices have neither succeeded in changing students' attitudes and emotions about other groups members, nor have they succeeded in transforming conflictual relationships, between different social-ethnic-religious groups, into relationships of trust, understanding, and reciprocity. In this article, I review the accepted practices of peace education and suggest a potential explanation of the failure of these practices. The main purposes of the article are first to argue that many educators, who engage in peace education, aspire to cultivate tolerant, or even pluralistic relationships among the conflicting groups, while not engendering intercultural relationships that might 'endanger' group identities. The second purpose is to suggest a possible solution, namely, to use humor. Using humor in peace education - in a way that is cognizant of the different cultural sensitivities - might lead to attentive dialogue among the groups and improve peace education's effectiveness.
\end{abstract}

Keywords: humor, interculturalism, multiculturalism, peace education

\section{Introduction}

Alienation, racism, and hostility among members of different social-ethnic-religious-national groups in Israel society threaten citizens' security, their moral identity, and the democratic society's stability. Educators, who aspire to promote the growth and wellbeing of society's young members, and in general, aspire to ensure sustainability (Jing, Brantmeier, Bruhn, 2008), must do whatever they can to facilitate a change of attitudes and emotions in relation to other groups members. This will make it possible for them to turn the conflictual relationships between the groups into relationships characterized by dialogue, trust, acquaintance, understanding, reciprocity, and cooperation. Therefore, educators should incorporate peace education in all aspects of the educational system.

Despite this, peace education has not been afforded a central place in the formal educational system in Israel. The Israeli educational system is divided into separate sectors (secular Jewish, national religious Jewish, orthodox Jewish, and Arab). There is no formal policy for peace education in any of the sectors. However, there are few examples of integrated (mixed Jewish and Arab) schools. Furthermore, in many districts of the Ministry of Education, there are active "islands" of shared life education that focus primarily, but not exclusively, on Jewish-Arab relations, organized mainly by non-profit organizations (Salomon \& Issawi, 2009).

Following Bar-Tal and Rosen (2009), Harris (2010), Salomon \& Issawi (2009), and Salomon \& Cairns (2010), I understand this disregard of peace education, by education authorities and policymakers, as being due to three main reasons. (a.) There is pressure to add more mathematics and science courses in the curriculum, which are perceived as helping school graduates to better succeed in the global labor market. This leaves less time for peace education. (b.) There is ongoing violence, on the Israel-Gaza/Hamas front, between Israel and the Palestinians in the West Bank, and threats from Hezbollah in Syria and Lebanon. This violence, as well as the global terrorist threats, which have intensified over the last two decades, hinder the readiness of educational authorities to adopt a policy that could be construed as opposing the government's War on Terror policy, and as potentially weakening the Jewish-Israeli collective narrative. Generally, peace education policy is construed as harming the population's motivation for struggle. (c.) The widespread public atmosphere in Israel, characteristic 
of recent years, encourages divisiveness and separation. One example of this divisiveness is the debate over the Nation Basic Law that was legislated in 2018. More examples are the 2019/2020 election campaigns' hateful messages, the struggles during the Corona period between right and left, and the clashes between ultra-Orthodox Jews and police officers who are perceived as representatives of the secular sector.

Even when peace education practices are actually implemented in the educational system, social-political and military events and developments, and the tensed public atmosphere, enormously weaken the chances of attitude's change and of turning the confrontational relationships between society's different groups into relationships of respect, understanding and cooperation. This is true of the religious and secular, Ashkenazi and Mizrahi (Note 1) veteran and newcomers, left and right, and Arabs and Jews, divides.

Bar-Tal \& Rosen (2009) argue that peace education in the educational system can succeed; contribute to a shared life in the country, based on tolerance, respect, and equality, only when there is a transformation in social and political conditions. I, however, tend to agree with Salomon \& Cairns (2010b) and argue that we should not wait until the social-political conditions change in order to implement peace education. The main goal of this article is to argue that if we persevere with peace education, implement it in creative ways and include humor, as I propose below, it can actually lead intercultural dialogues that might change the social and political conditions themselves.

\section{Peace Education: Aims}

Peace education, which is rooted in the nineteenth century but became much more developed and formalized after the Second World War, is systematic educational practice, which usually occurs in contexts of conflict between groups inside and outside of a country. In this practice, an effort has been done to provide students with knowledge, skills and dispositions that eventually lead to peace consciousness and peace culture. This can bring us closer to a peaceful world that works to create unity in contexts of diversity and to ensure that all people are realizing their human rights (Adams, 2013; Bajaj, 2008, 2019; Danesh, 2011; Galtung, 2008; Harris, 2010; Harris \& Morrison, 2013; Jing et al., 2008; Lum, 2014; Salomon \& Cairns, 2010; Snauwaert, 2008; Synott, 2005).

Peace education helps to fulfill what is, in my opinion, the overall goal of education: to enable people to fully experience a productive, compassionate, and meaningful existence (Harris \& Morrison, 2013; Lum, 2014; Noddings, 2012). However, as nowadays many theoreticians and practitioners understand the major role of education as the reinforcement of existing society, peace education is often perceived as adopting 'resistance', 'radical' and other counter-hegemonic positions (Synott, 2005).

Johan Galtung $(1964,1969,2008)$, one of the founders of peace education, distinguished between two kinds of peace. 'Negative' peace represents the absence of organized violence and hostilities. The other kind - 'positive' peace, represents a balance, harmony, and interplay of opposites that constitute a living, interdependent dynamic. Later Galtung added another concept, 'structural peace' - the absence of structural or indirect violence. Structural violence refers to inequality in power and in opportunities for self-fulfillment (Jing et al., 2008; Leeds, 2009; Lum, 2017; Salomon, 2000). Peace education seeks to lead society to processes of peaceful existence in all three kinds of 'peace' (Bar Tal \& Rosen, 2009; Harris, 2010; Lum, 2017) (Note 2).

The goals of peace education emerge from and are compatible with progressive assumptions concerning human nature, which is basically good, cooperative, and striving for peace. According to these assumptions the identity notions of the 'self', the 'other', 'we', or 'the enemy', are always learned, as opposed to inborn. In order to deconstruct and challenge the authority of such notions, peace educators encourage students to identify the social and cultural traditions that camouflage people's essential goodness (Synott, 2005). Peace education focuses on changing attitudes and transforming narratives relating to a collective 'other', attitudes and narratives that contain stereotypes, prejudice, delegitimization, and dehumanization of the opponent as well as biased self-perceptions. Changing this intergroup negative psychological repertoire is also connected to changing emotions associated with a collective 'other': reducing anger, distrust, fear, and hate, and alternatively, building trust and empathy. Changing behavioral intentions; creating mutual recognition, equality, and cooperation, instead of discrimination, exploitation, deportation, vengeance, and even genocide, is part of the desired repertoire change as well (Bar-Tal \& Rosen, 2009; Salomon, 2000).

Apart from changing the psychological repertoire, peace education also fosters values of peace and democracy: justice, cooperation, solidarity, and increases the readiness for concessions for peace. Peace education acts on changing people's worldviews, from worldviews of inevitable conflict and absence of unity to worldviews of peace, healing, unification, cooperation, and excellence (Bar-Tal \& Rosen, 2009; Danesh, 2011; Salomon, 2000; Shasha-Byton, 2010; Synott, 2005). 
Since the onset of the twenty-first century, peace education has expanded to include a cultivation of the cosmological, environmental, and global perspective. A perspective of human being as a living system in relation with all other living systems on earth. The assumption is that regenerating peaceful relations with all living creatures, and with the natural world is a critical step in the wellbeing and survival of human civilization (Lum, 2014, 2017; Synott, 2005).

\section{Peace Education: Practices}

Although peace education is based on academic disciplines (social psychology, political psychology, philosophy, communication) which determine its goals and strategies, translating these disciplines into actual educational practices is far from simple. The literature does not offer systematic pedagogical models that can guide educators who strive to decrease tension among groups and lead to a culture of peace (Salomon \& Cairns, 2010, 2010b).

Peace education is a kind of "umbrella" that includes many different programs that deal with issues of social justice and the building of a culture of peace. These programs have been undertaken in different societies, different contexts, with different ages, and with different time spans. They have adopted different ways of acting and have different outcome objectives. For example, there are programs for violence prevention, conflict resolution, mediation, effective communication, reconciliation, human rights education, multicultural and intercultural education, education for democracy, dialogue encounters, environmental preservation, and the prevention of the proliferation of nuclear weapons (Note 3) (Bajaj, 2008; Harris, 2010; Salomon, 2000; Salomon \& Cairns, 2010).

In general, education for peace can be implemented in several circles of the educational system:

1. In the nurturing of a school culture, which does not tolerate offensive, violent, and racist contents and behaviors. Schools that nurture such a culture also combine teachers from different groups, routinely engage in peace education training for teachers, and initiate, in collaboration with non-profit organizations, activities that encourage acquaintance with the largest community and encourage coping with depressing situations. Additionally, these schools nurture a culture which is largely based on cooperative and dialogical learning, and on creating a democratic community (Galtung, 2008; Harris, 1988; Noddings, 2012; Salomon \& Issawi, 2009) (Note 4).

2. In the incorporation of different content in citizenship studies curricula, and in other subject areas, such as geography, history, literature, languages, social sciences, the arts, communication, and cinematography. Depending on the subject being taught, the students' ages and their level of readiness, and the characteristics of the teacher-student relationships, the content can deal with different areas. These include democratic values, human rights, political and social conflicts, war and peace processes, current affairs, identity, group's psychological repertoire, human tendencies for love and war, and gaining knowledge about the different groups in one's society (Bar-Tal and Rosen, 2009; Gur-Ziv, 2013; Noddings, 2012; Salomon \& Issawi, 2009; Salomon, 2000).

In recent years, there has been a rise in critical approaches to peace education. These approaches offer peace educators the contextual and conceptual resources for understanding power dynamics that exist in different forms of stratification (Bajaj, 2019; Cabezudo \& Haavelsrud, 2013; Jing, 2008).

Synott (2005) notes that the learning process in peace education is primarily an experiential and activity-based process. This is not a learning process characterized by rote memorization or by repetitive conditioning because one cannot indoctrinate peace education.

3. In the development of capabilities and skills at the individual level and in inter-personal relationships. This includes reflective and critical thinking, mediation and conflict resolution skills, managing effective communication, anger control, solving problems in compromising and creative ways, cooperation, tolerance, and empathy (Bar-Tal \& Rosen, 2009; Gur Ziv, 2013; Salomon, 2000; Salomon \& Issawi, 2009).

4. In the establishment of integrated schools for members of conflict groups, and in the undertaking of actual or virtual encounters between conflict groups that include collaborative activities and studies. These encounters, which are professionally facilitated, usually last at least one year (Gur Ziv, 2013; Maoz, 2010; Salomon, 2009; Salomon \& Issawi, 2009).

\section{The Israeli Case}

Although peace education is not formally implemented in the education system in Israel, it is rather widespread, and it is informally implemented by using many of the above practices. Yet it's success in changing attitudes and emotions and in turning the relationships between the groups into relationships of respect, understanding, and 
cooperation is questionable. Following Bar-Tal \&Rosen (2009), and Salomon \& Issawi (2009), I assume that the military and political conditions and the public atmosphere in Israel which encourages divisiveness and separation hinder the success' chances of peace education. Hereinafter is a possible explanation as to the way in which the public atmosphere fails the success of peace education.

My explanation is that many educators, who implement peace education, try to foster tolerance between the conflict groups. They may even be interested in fostering pluralistic relationships. However, they rarely attempt to promote multicultural or intercultural relationships.

Sagi (1999) distinguishes between the concepts of tolerance, pluralism, and multiculturalism. According to this distinction, tolerance means that although I do not agree with the position, belief, historical narrative, or way of life of the other, I understand that the other person or group has a legal or moral right to adopt it. When the relationships between individuals and groups are characterized by tolerance, there is no place for real dialogue, in which the participants 'turn to each other's face' (in Levinas' [1974] terms, as cited in Sagi, 1999), listen to them, and even narrow themselves to leave room for the others. According to the German philosopher Hegel (1896, cited in Sagi, 1999), in a dialogue as turning to the other's face, there is a great measure of danger. When a person opens oneself to the other, s/he risks her/his former identity. Dialogue partners know how they begin the dialogue, but do not know how they will end it. In this context, Hegel spoke of a 'struggle for life and death', because something might die, just as something else might come to life (Sagi, 1999).

The term 'pluralism' has two meanings - 'weak' meaning and a 'strong' meaning (Sagi, 1999). 'Weak' pluralism assumes that only one attitude, belief, narrative or way of life is right or good. However, because the discourse partners do not know for sure which attitude, belief, narrative, or way of life is the right or the good one, they must guarantee free speech and thought for all (Mill, 1859). 'Strong' pluralism assumes that we cannot compare values, attitudes, or narratives, which are imbued with subjective memories and emotions (Nodings, 2012), or compare different ways of life, using a single criterion. Many values, attitudes, memories, and ways of life have an intrinsic value, and people have the right to embrace them, because they are valuable for them (Sagi, 1999).

Multiculturalism (Note 5) assumes that individual and social identities are formed by having dialogues with others that offer relevant alternatives to the life organization of those individuals and societies (Taylor, 1994). Awareness that the other can offer a relevant and meaningful alternative to the way our lives are organized, may lead individuals and societies away from rejection, negation, and conflictual relationships to dialogical relationships with others who are meaningful to those individuals and groups (Sagi, 1999).

From the beginning of the 2000s, it has been customary to distinguish between the concept of multiculturalism and the concept of interculturalism. Both concepts point to a perception that strives for unity within diversity, but while the first emphasizes the diversity the second rather emphasizes unity. The term "interculturalism" is more appropriate for Israel since Israel tries to maintain democracy while preserving the Jewish character of the state. In fact, the way in which Sagi (1999) characterizes the multicultural stance is also more appropriate for what is known today as "interculturalism". Therefore, later in the article I use the term "interculturalism" while adopting the meaning that Sagi gives to the term "multiculturalism".

Against the background of the above distinction I would like to note that throughout multiple encounters with teachers which I have as teacher educator in the last twelve years, I have noticed that most educators, who embrace peace education, try to foster tolerant relationships between groups in conflict. These efforts are based on their assumption that every person and group have a legal or moral right to adopt their own attitudes, or ways of life, even if these attitudes and ways of life, are mistaken.

Some Israeli educators, so I have noticed, adopt 'weak' pluralistic stance and assume that we do not know for sure which position, or way of life, is the right or the good one. As a result, we must ensure free speech and thought for everyone. I have further discerned that there are some educators in Israel who adopt 'strong' pluralism because they assume that it is impossible to compare values or ways of life as well as different historical narratives and memories using single criteria. Many values, narratives, and ways of life, they think, have intrinsic value: they are true and good for the people who adopt them, and people should be allowed to do so. Educators, who adopt a pluralistic stance, foster relationships of interest, curiosity, and openness. They encourage their students to become acquainted with the other's opinions and practices (Schlanger, 2000).

However, I have noticed that most Israeli peace educators which I have met do not accept the intercultural view, as it was described above. As part of the public atmosphere in Israel most groups, especially Jews as opposed to Arabs, religious in front of non-religious Jews, and people who belong to the political groups of right and left, do not see the other group member as a significant other in the dialogue with whom their group identity is shaped. Even If, in the past, most groups formed their own identities in response to the attitudes, values, and ways of life 
of other groups, the vast majority of people have not made the consciousness' change to identify the influence of the other's attitudes, values and ways of life on one's identity. Taylor (2012) argues that the Achilles heel of the intercultural story is the fears it can arouse that "they" may change our whole way of life. Therefore, most people in Israel (educators included) resist to enter into a real dialogue with the other, to make a genuine attempt to listen to the other, and to clarify their own attitudes, in relation to the other's (Schlanger, 2000) (Note 6).

Empirical support for this impression can be found in a large-scale study undertaken by Bekerman, Zembylas, and McGlynn (2009). Part of this study focused on an analysis of five integrated (Jewish-Arab) schools in Israel, schools in which both Hebrew and Arabic are the languages of instruction. In these schools, in each class, there are two teachers, one Arab and one Jew. The researchers found that even in these schools, which directly encourage coexistence, teachers deal with national and religious issues with a manifest twofold goal: to support integration toward coexistence, while, at the same time, safeguarding and strengthening individual identity and sense of belonging to each student's 'original group'. These teachers hold essentialist perspectives about ethnic/religious origin; they are strict in maintaining a rule of 'do not cross identity borders.' They appear to emphasize the importance of children understanding to which specific group and tradition they are connected. These teachers are very tolerant of each group's rites, festivals, texts, historical narratives, and other cultural and national artifacts and habits; they can even be described as holding pluralistic beliefs and acting in non-judgmental ways regarding all attitudes and ways of life. However, the teachers do not appear to be intercultural, there is no evidence of their encouragement of real dialogue and mutual influence of the groups.

\section{Humor and Peace Education}

A possible way to make teachers intercultural and increase peace education success might be by encouraging them to integrate humor in a systematic and intentional fashion in peace education practices.

I use the term 'humor' in a wide manner. Humor is a tendency to experience or use diverse strategies that cause emotional response and vocal-behavioral expressions such as laughter and smiling, from the listeners/readers. They suddenly catch the surprising intersection of frames of reference that are usually unrelated to one another, incongruence between ideas, double meanings, or the absurdity or exaggeration of expressions, behaviors, and situations. Jokes and caricatures are the most efficient expressions of humor. However, humor is also conveyed through word games, wit, and riddles. Expressions of humor are found in all known cultures (Jiang et al., 2019; Leeds, 2009; Niebylski, 2004; Suber, 2009).

Much has been written about humor, as a coping mechanism that lessens stress, worry, and fears and helps to heal illness and improve health. Humor and laughter serve as a shortcut to closeness: they help to reduce hostility, built trust, and break down barriers (Leeds, 2009; Suber, 2009; Ziv, 1995). Freud (1905, 1990) was one of the first psychologists, who argued that humor helps people channel sexual and aggressive feelings in a hidden way and to cope with feelings of anger and frustration. According to Freud (in Suber, 2009 and in Leeds, 2009), forms of humor that involve linguistic manipulation enable us to return to a childish world characterized by chaos, the breaking of rules, and surprise. Humor provides temporary legitimation for deviating from the strict borders of rational and practical thought and enables people to engage in creative play with new ideas.

One of the central threats to spousal, social, and political harmony, and to physiological wellbeing, is our wish to strengthen our own ego. People tend to be strict in their desire to defend their beliefs and attitudes, at all costs. Humor that can offer an alternative perspective on issues that concern us, helps us become less strict and arrogant and frees us from the constraints that derive from egoism and arrogance (Leeds, 2009) (Note 7).

Kohls (1996) points to the use of humor as an important skill for integration in a foreign country because humor is an indication that the person involved can step back from the current situation and look at one's own position and that of the interaction partners from a different perspective.

Niebylski (2004) demonstrated how humor, in works by contemporary Latin-American writers, creates a subversive discourse that reveals oppressive social and cultural institutions and stimulates thought concerning stereotypical conceptions. Christopher Leeds (2009), suggested a new paradigm, 'peace humor', and emphasized the importance of its use in building a better and safer world - a unified world that abandons violence as means of conflict resolution - and in cultivating a culture of peace (Note 8).

In addition to its ability to act against stress and suspicion, peace humor further serves as a lubricant to soften the edges of taboos, stereotypes, intolerance, and the inability to concern alternative attitudes. Peace humor reveals the madness and futility of violent conflict and can help lead to an understanding that peace should be adopted for dealing with disagreement between states. Leeds (2009) stresses the importance of using peace humor in the context of entertainment shows and argues that when entertainers humorously attack violent conflict and war, the 
chances of building a peaceful world increase. Humor not only helps people avoid narrow-mindedness, racist attitudes, and tunnel vision, which can prevent peaceful conflict resolution, but also encourages openness and creative thinking. These are qualities, which are important for solving problems, for effective negotiation, and for finding ways out of dead ends.

There are now quite a few entertainers in the western world as well as in Israel, who promote peace culture by using humor. The comic television series, 'Arab Labor,' which aired on Israeli television from 2007-2013, and portrayed Arab-Jewish relations in Israel in a humorous way, was based on a similar rationale. Goren (2014) offers an interpretive reading of one of its episodes and argues that the episode challenges the simplistic division of Jewish-Israeli and Palestinian histories into two separate narratives that can neither contain one another nor exist one alongside the other. This separation of narratives preserves the complete separation between the sides. The use of a situational comedy creates a space for different thinking about social dogmas and collective memory, a thinking that allows the creation of a new narrative that takes both narratives into account.

I think that it is worthwhile to apply peace humor in the context of peace education as well as in the context of political satire. Using humor that breaks down the barriers of suspicion, fear, and hostility, might have the potential to lead students and teachers to develop a willingness to look at their own narratives in a more critical way, taking into account some alternative attitudes, and go beyond their exclusive victim identity's stand. Adopting humor into peace education practices allows for an intercultural dialogue in which both sides continuously redesigning their own identities while becoming acquainted with the other side's identity.

Including humor strategies in peace education can be done by having students create and reflect on humorous texts and films that deal with intercultural relationships. Humorous and witty puzzle competitions between groups can be held as well. These competitions, much like other project-oriented encounters, can channel tensions and anger into nonviolent activities. Another possibility is that members of different cultures tell jokes and funny stories and fables of their own culture and explain the respective humorous aspects. It is even possible to have confrontational encounters between groups, in which the conflict is contemplated from a humorous perspective. Like narrative encounters between groups (Maoz, 2010), the use of humor can crack the walls of the narratives behind which the parties are defending, because it diminishes concerns and inspire parties to rethink their narratives, while seeing the complexity of the conflict (Note 9).

Implementing peace humor in peace education practices may start an intercultural dialogue. In such a dialogue each party is required to relinquish the exclusive victim's position, to acknowledge its part in causing injustice, to recognize the interests of the other party, to listen to the other party's position, and even to be ready to be convinced by the other's righteousness. It can cause people to take a 'risk' of losing or changing their former identity (Sagi, 1999).

\section{Difficulties}

Although humor is a universal phenomenon found in all cultures, the usual forms, contents, and situations that are considered appropriate for using humor vary from culture to culture, and from person to person. Jiang et al. (2019) review researches that show that Easterners and Westerners apply all types of humor (self-enhancing, affiliative, self-defeating, and aggressive) in different manners and that Easterners tend to use less aggressive but more affiliative humor than Westerners. What one person perceives as funny can be perceived by others as silly, boring, or offensive. Much depends on education, culture, and tastes, as well as on the timing (Jiang et al., 2019; Leeds, 2009). I would like to add that humor is to a large extent, an emic phenomenon because it often refers to previous cultural or linguistic knowledge and cannot easily understood by different culture's members. Sometimes it might even be misunderstood and thus lead to intercultural conflicts.

In this context, it is worth mentioning the violent riots that took place in Denmark in 2005 and in France in 2015 and the beheading of the teacher in France on October 2020. The severe riots and the inconceivable case of decapitation, caused by the cartoons which portrayed the Prophet Muhammad, expressed Muslims' sensitivities toward humor that deals with the Prophet and perceived as extremely offensive and not at all amusing. The Muslims' attitudes concerning humor that deals with the Prophet reflects a widespread conception of humor. According to this conception, first noted by Plato, using humor ridicules the story of others and their weaknesses. As a result, it degrades and lowers them (Suber, 2009).

Thomas Hobbes (1651) argued that laughter expresses a sense of superiority of an individual or group over weakness, real or imagined, or the misfortune of others. It increases self-esteem at the expense of others. Bergson (1960) argued that laughter intends to humiliate the extraordinary people it targets, to cause them to have an unpleasant feeling and, thus, suppress them or their activities that are perceived as being deviant. Stiller-Timor (2019) argues that the long-standing prejudice against the use of humor is primarily directed 
against humor in the context of a tragic event. The tragedy, whether on stage or in real life, is serious, even sublime, while humor and comedy are 'light.'

This widespread conception of humor and the specific cultural sensitivities concerning use of certain types and content of humor may, therefore, raise concerns and explain the avoidance of using humor in the context of peace education.

I believe that the differential sensitivity of different (especially conservative) groups with regard to humor and its perception as offensive and humiliating, does indeed require us to exercise discretion while using humor. This requires some recognition and awareness of the other group's values and sensibilities. However, I do not think that the differential sensitivity of groups regarding humor should direct us to avoid using it in the discourse. Leeds (2009) argues that in order to use peace humor effectively we must be self-confident and assertive. At the same time, we must be capable of seeing other people and societies, including our own, from the perspective of others. Of equal importance is the ability to be open-minded and caring, that is, we need to appreciate the interests of others.

\section{Conclusions and Summary}

In Israel's divided society, it is important that educators integrate peace education into all dimensions of doing and learning in the educational system; indeed, many schools in Israel undertake varied practices of peace education. However, these practices rarely succeed in transforming the conflict relationships between groups into relationships of understanding and respect. In this article, I argued that this might be to a large extent because although many educators in Israel strive to cultivate inter-group relationships characterized by tolerance, perhaps even encouraging pluralist relationships, they do not really aspire to cultivate intercultural relationships.

Based on some accepted assumptions concerning humor use and influence I argue that integrating humor into peace education practices can lead to intercultural (critical and empathetic) discussion and dialogue among groups. It can create a change in the parties' attitudes and emotions and increase the chances of peace education's success.

In general, peace education does not involve peace humor practices, probably because of the assumption that humor might degrade and offence people. Although this article's arguments should still be supported by empirical evidence I think that as teacher educators we must encourage teachers to incorporate humor into the practices of peace education while taking into account the values and sensitivities of members of different groups. At the same we want teachers to recognize that inter-group dialogue enriches - as opposed to harming the identities of the different sides. As educators of teachers, we should strengthen values of humility, self criticism and respect. We must encourage dialogue processes and mutual enrichment, openness towards one another, and mutual learning. We must foster an understanding that no culture contains a monopoly on the truth or the right. There is not only one good thing worth living, but there are many good ideas, values, and ways of understanding the world and living. found in different cultures. It is important to recognize that different cultures, living together in a dialogical manner, may create constructive and inspiring tension that has the potential to enrich the identity of each side.

\section{References}

Adams, D. (2013). Education for a Culture of Peace: The Culture of Peace News Network as a Case Study. Journal of Peace Education, 10(3), 230-241. https://doi.org/10.1080/17400201.2013.846564

Bajaj, M. (2008). Introduction. In M. Bajaj (Ed.), Encyclopedia of peace education (pp. 1-12). Charlotte, N.C: Information Age Publishing.

Bajaj, M. (2019). Conceptualizing Critical Peace Education for Conflict Settings. Education and Conflict Review, 2, 65-69.

Bekerman, Z., Zembylas, M., \& McGlynn, C. (2009). Working toward the De-essentialization of Identity Categories in Conflict and Post-Conflict Societies: Israel, Cyprus and Northern Ireland. Comparative Educational Review, 5(2), 213-234. https://doi.org/10.1086/597482

Bar-Tal, D., \& Rosen, Y. (2009). Education in Societies involved in Intractable Conflicts: Direct and Indirect Models. Review of Educational Research, 79(2), 557-575. https://doi.org/10.3102/0034654308330969

Bergson, H. (1960). Laughter: An Essay on the Meaning of the Comic. New York, NY: Macmillan.

Cabezudo, A., \& Haavelsrud, M. (2013). Rethinking Peace Education. Journal of Conflictology, 4(1), 3-13. https://doi.org/10.7238/joc.v4i1.1521 
Danesh, H. B. (2011). Education for Peace Reader: Education for a Peace Integrative Curriculum. Victoria, Alberta: EFP Press.

Freire, P., \& Shor, I. (1987). A Pedagogy of Liberation. London, UK: Macmillan Education. https://doi.org/10.1007/978-1-349-18574-0

Freud, S. (1905/1990). Jokes and their Relation to the Unconscious. New York, NY: W.W. Norton \& Company.

Galtung, J. (1964). An Editorial. Journal of Peace Research, 1(1), 1-4. https://doi.org/10.1177/002234336400100101

Galtung, J. (1969). Violence, Peace and Peace Research. Journal of Peace Research, 6(3), 167-191. https://doi.org/10.1177/002234336900600301

Galtung, J. (2008). Form and Content of Peace Education. In M. Bajaj (Ed.), Encyclopedia of Peace Education, (pp. 49-58). Charlotte, NC: Information Age Publishing Inc.

Goren, S. (2014). Humor, Violence, and Creative Resistance in the TV Series Arab Labor. Studies in Israeli and Modern Jewish Society, [Iyunim Bitkumat Israel], Multidisciplinary Journal of Israel Research, 24, 73-93.

Gur-Ziv, H. (2013). Critical-Feminist Pedagogy and Peace Culture Education. Tel-Aviv: Mofet Institute.

Harris, I. M. (2010). History of Peace Education. In G. Salomon \& E. Cairns (Eds.), Handbook of Peace Education (pp. 11-20). New York, NY: Psychology Press.

Harris, I. M., \& Morrison, M. L. (2013). Peace Education. NC and London: McFarland \&Company, Inc., Publishers.

Hobbes, T. (1651). Leviathan: Or the Matter, Form and Power of a Commonwealth, Ecclesiastical and Civil. London, UK: Andrew Crooke.

Jiang, T., Li, H., \& Hou, Y. (2019). Cultural differences in humor perception, usage, and implications. Frontiers in Psychology, 10(January), 123. https://doi.org/10.3389/fpsyg.2019.00123

Jing, L., Brantmeier, E., \& Bruhn, C. (2008). Introduction. In L. Jing, E. Brantmeier \& C. Bruhn (Eds.), Transforming Education for Peace (pp. XIII-XVIII). Charlotte, NC: Information Age Publishing Inc.

Kashua, S., Faran, D., Ninio, R., \& Capon, S. (2007-2013). Arab Labor. Israel: Keshet Broadcasting.

Kohls, R. L. (1996). Survival kit for overseas living. For Americans planning to live and work abroad. Yarmouth: Intercultural Press.

Kymlicka, W. (1995). Multicultural Citizenship. Oxford, UK: Clarendon Press. https://doi.org/10.1093/0198290918.001.0001

Leeds, C. A. (2009). Peace Humor. In A. Aharoni (Ed.), Peace, literature, and art, II (pp.1-48). Encyclopedia of life support systems (EOLSS).

Lum, J. B. (2014). Peace Gardens: Transforming Schools for Global Peace. Peace and Policy, 19, 119-138.

Lum, J. B. (2017). Introduction. In J. Lum (Ed.), Peace education: Past, present, and future (pp. 1-5). USA \& UK: Routledge, Taylor \& Francis.

Maoz, I. (2010). Educating for Peace through Planned Encounters between Jews and Arabs in Israel, A Reappraisal of Effectiveness. In G. Salomon \& E. Cairns (Eds.), Handbook on peace education (pp. 303-313). New York, NY: Psychology Press.

Mill, J. S. (1859). On Liberty. London, UK: Parker \& Son.

Niebylski, D. C. (2004). Humoring Resistance: Laugher and the Excessive Body in Latin American Women's Fiction. Albany, NY: State University of New York Press.

Noddings, N. (2012). Peace Education: How We Come to Loveand Hate War. New York, NY: Cambridge University Press. https://doi.org/10.1017/CBO9780511894725

Nussbaum, M. (2016). Not for Profit: Why Democracy Needs the Humanities. Princeton, NJ and Oxford, UK: Princeton University Press. https://doi.org/10.2307/j.ctvc77dh6

Sagi, A. (1999). On the Tensions between Religious and Secular - between a Rights Discourse and an Identity Discourse. In N. Ilan (Ed.), A Good Eye, Dialogue and Polemic in Jewish Culture (pp. 408-432). Tel Aviv: Hakibbutz Hameuhad.

Salomon, G. (2000). Peace Education: Is it Possible without Research? The Israel Education Study Society 
Conference: Tel-Aviv (24/10).

Salomon, G. (2009). Peace Dialogue in Times of Conflict. In N. Aloni (Ed.), Empowering Dialogues in Humanistic Education (pp. 382-297). Tel-Aviv: Hakibbutz Hameuchad. (Hebrew).

Salomon, G., \& Edward, C. (2010). Peace Education: Setting the Scene. In G. Salomon \& E. Cairns (Eds.), Handbook on Peace Education (pp. 1-7). New York, NY: Psychology Press.

Salomon, G., \& Issawi, M. (2009). Report of the Public Committee for the Formation of State Policy on Education for a Joint Life between Jews and Arabs in Israel. Jerusalem: The Ministry of Education.

Salomon, G., \& Cairns, E. (2010b). Open-Ended Questions. In G. Salomon \& E. Cairns (Eds.), Handbook on Peace Education (pp. 315-332). New York, NY: Psychology Press.

Schlanger, J. (2000). On Mutual Respect and Self-Respect. In A. Hareven \& C. Bram (Eds.), Human Dignity or Humiliation? The Tension of Human Dignity in Israel (pp. 34-43). Tel Aviv: Van Leer Institute and the Hakibbutz Hameuchad Publishing House.

Shasha-Biton, Y. (2010). What do You Mean when You Say 'Peace'?. Studies in Education, 3, 94-75.

Snauwaert, D. T. (2008). The Moral and Spiritual Foundations of Peace Education. In M. Bajaj (Ed.), Encyclopedia of Peace Education (pp. 67-71). Charlotte, NC: Information Age Publishing Inc.

Stiller-Timor, I. (2019). The Tragic Comic Humor in Israeli Comics about the Holocaust: Intergenerational Communication, between the Holocaust and its Rebirth. Online Humor, 12(June), 20-43.

Suber, A. (2009). Humor, in the Way of the Laughing Man. Jerusalem: Carmel Press.

Synott, J. (2005). Peace Education as an Educational Paradigm: Review of a Changing Field using an Old Measure. Journal of Peace Education, 2(1), 3-16. https://doi.org/10.1080/1740020052000341786

Tadmor, I. (2007). Education as an Existential Experience. Tel-Aviv: Mofet Institute.

Taylor, C. (1994). Multiculturalism: Examining the Politics of recognition. Princeton, NJ: Princeton University Press. https://doi.org/10.2307/j.ctt7snkj

Taylor, C. (2012). Interculturalism or multiculturalism? Philosophy and Social Criticism, 38(4-5), 413-423. https://doi.org/10.1177/0191453711435656

Ziv, A. (1995). The Humor Study in Education: A Quarter Century. In D. Chen (Ed.), Twentieth Century Education: The Twentieth Anniversary Book of the School of Education at Tel-Aviv University (pp. 517-523). Ramat Aviv: Tel Aviv Universit.

\section{Notes}

Note 1. 'Ashkenazi' and 'Mizrahi' [Hebrew] denote Jews from two main different ethnic backgrounds.

Note 2. Many scholars include in 'positive' peace the absence of structural and cultural violence or the promotion of a sustainable, just and equitable society (Bajaj, 2019; Cabezudo \& Haavelsrud, 2013).

Note 3. There are some disagreements concerning the relations of peace education and other educational paradigms as intercultural education or pedagogy of empathy. For the purposes of this article there is no need to get into these disputes.

Note 4. Some of the learning models in peace education are compatible with the approaches of Freire and Shor (1987), in their advocacy of dialogic teaching/learning. In peace education, where there is a strong emphasis on behavioral skills, the dialogic and participatory processes are central to the learning experience (Synott, 2005).

Note 5. My analysis is based on Taylor's (1994) conception of multiculturalism and not on Kymlicka's (1995) conception that resembles the strong pluralism (Sagi, 1999), and relies on principles of justice.

Note 6. A somehow similar assumption can be found in Tadmor (2007).

Note 7. It is interesting to note that while Westerners regard humor as a desirable trait, associate humor with positivity and stress the importance of humor in daily life, people from East Asia have ambivalent attitudes toward humor. Chinese people, for example, might sometimes admit that humor is important in daily life, but they do not see themselves or their relatives as humorous people. Accordingly, it was found that Easterners were less likely to use humor as coping strategy with stress or difficulties than Westerners (Jiang et al. 2019). 
Note 8. Discussion of topics related to military or political humor first appeared in journals in 1995, but the term, 'peace humor', was first coined at an international peace research conference held in Hungary in 2004 (Leeds, 2009).

Note 9. Nussbaum (2016) argues that for developing our ability to see the humanity in people towards whom we hold biased opinions we need an enjoyable experience, and therefore she proposes to use humanities and arts. I think humor could do better!

\section{Copyrights}

Copyright for this article is retained by the author(s), with first publication rights granted to the journal.

This is an open-access article distributed under the terms and conditions of the Creative Commons Attribution license (http://creativecommons.org/licenses/by/4.0/). 